\title{
Two novel atypical PKC inhibitors; ACPD and DNDA effectively mitigate cell proliferation and epithelial to mesenchymal transition of metastatic melanoma while inducing apoptosis
}

\author{
WISHRAWANA S. RATNAYAKE ${ }^{1}$, ANDRÉ H. APOSTOLATOS ${ }^{1}$, \\ DAVID A. OSTROV ${ }^{2}$ and MILDRED ACEVEDO-DUNCAN ${ }^{1}$ \\ ${ }^{1}$ Department of Chemistry, University of South Florida, Tampa, FL 33620; ${ }^{2}$ Department of Pathology, \\ Immunology and Laboratory Medicine, University of Florida, College of Medicine, Gainesville, FL 32610, USA
}

Received June 12, 2017; Accepted September 18, 2017

DOI: $10.3892 /$ ijo.2017.4131

\begin{abstract}
Atypical protein kinase Cs (aPKC) are involved in cell cycle progression, tumorigenesis, cell survival and migration in many cancers. We believe that aPKCs play an important role in cell motility of melanoma by regulating cell signaling pathways and inducing epithelial to mesenchymal transition (EMT). We have investigated the effects of two novel aPKC inhibitors; 2-acetyl-1,3-cyclopentanedione (ACPD) and 3,4-diaminonaphthalene-2,7-disulfonic acid (DNDA) on cell proliferation, apoptosis, migration and invasion of two malignant melanoma cell lines compared to normal melanocytes. Molecular docking data suggested that both inhibitors specifically bind to protein kinase C-zeta (PKC- $\zeta$ ) and $\mathrm{PKC}$-iota $(\mathrm{PKC}-\mathrm{\iota})$ and kinase activity assays were carried out to confirm these observations. Both inhibitors decreased the levels of total and phosphorylated PKC- $\zeta$ and PKC-ı. Increased levels of E-cadherin, RhoA, PTEN and decreased levels of phosphorylated vimentin, total vimentin, CD44, $\beta$-catenin and phosphorylated AKT in inhibitor treated cells. This suggests that inhibition of both PKC- $\zeta$ and PKC-ı using ACPD and DNDA downregulates EMT and induces apoptosis in melanoma cells. We also carried out PKC-ı and PKC- $\zeta$ directed siRNA treatments to prove the above observations. Immunoprecipitation data suggested an association between PKC $-\iota$ and vimentin and PKC- $\iota$ siRNA treatments confirmed that $\mathrm{PKC}-\iota$ activates vimentin by phosphorylation. These results further suggested that PKC-ı is involved in signaling pathways which upregulate EMT and which can be effectively suppressed using ACPD and DNDA. Our results summarize that melanoma cells proliferate via aPKC/AKT/NF- $\mathrm{BB}$ medi-
\end{abstract}

Correspondence to: Dr Mildred Acevedo-Duncan, Department of Chemistry, University of South Florida, 4202 E Fowler Ave, CHE 205, Tampa, FL 33620, USA

E-mail: macevedo@usf.edu

Key words: melanoma, $\mathrm{PKC}-\mathrm{\iota}, \mathrm{PKC}-\zeta$, vimentin, EMT, migration, invasion, apoptosis, aPKC inhibitors ated pathway while inducing the EMT via PKC-ı/Par6/RhoA pathway. Overall, results show that aPKCs are essential for melanoma progression and metastasis, suggesting that ACPD and DNDA can be effectively used as potential therapeutic drugs for melanoma by inhibiting aPKCs.

\section{Introduction}

Melanoma is a type of cancer which occurs in melanocytes. Melanocytes are responsible for the production of the pigment melanin and are derived from the neural crest. Approximately $90 \%$ of melanoma occurs in skin (cutaneous melanoma), but it also rarely arises from the mucosal surfaces or areas which neural cells migrate. Examples are the eye, intestine and mouth. Malignant melanoma is very common among Caucasians (1). A total of 76,380 new cases of melanoma and 10,130 related deaths were expected in 2016 in the USA. Surgical resection, applications of immunotherapy, biologic therapy, radiation therapy, or chemotherapy may improve survival $(2,3)$.

PKC belongs to the protein kinase enzyme family which post-translationally modify other proteins by phosphorylation of hydroxyl groups of serine and threonine amino acid residues, so PKCs tend to be involved in many signal transduction cascades. There are 15 PKC isozymes identified in humans; they are divided as classical, novel and atypical (aPKCs). aPKCs contain two structurally and functionally distinct isozymes: PKC-ı and PKC- $\zeta$ which are involved in cell cycle progression, tumorigenesis, survival and migration in many cancers (4-7). Lung cancer cell proliferation is highly dependent on the PKC-ı level through activation of the ERK1 pathway (6). Overexpression of PKC-ı plays an important role in the leukemia chemoresistance (7). PKC-ı is also involved in glioma cell proliferation; it regulates the phosphorylation of cyclin dependent kinase activating kinase/cyclin dependent kinase 7 pathway $(8,9)$. Non-small lung cancer cell proliferation is highly dependent on PKC-ı (10). aPKCs are involved in TGF- $\beta$ induced EMT by phosphorylating Par6 (11). We believe that both aPKCs are involved in EMT process of melanoma cells by regulating the formation of vimentin intermediate filament (VIF) assembly. EMT is an important event of tumor progression where the apicobasolaterally polarized 
cohesive epithelial cells of epithelium detach from its basement and gain the ability of mesenchymal cells, which move independently. EMT is characterized by the loss of E-cadherin and gain of vimentin. During such morphological changes of cells in EMT, cytoskeletal intermediate filaments undergo a massive composition change by initiating the expression of vimentin. Even though the role of vimentin in EMT is not fully understood, some literature strongly supports the relevance of VIF assembly in EMT as being part of tumorigenesis $(12,13)$.

Selzer et al (14) has reported a comprehensive comparison of PKC isoform expression between normal melanocytes, transformed melanocytes and melanoma cell lines. PKC-ı may play a role in cellular malignancy as shown by its association with the transformed phenotype of human melanomas in vivo and in vitro. PKC-ı and PKC- $\zeta$ are overexpressed in both transformed and malignant melanoma. In comparison, $\mathrm{PKC}-\zeta$ was detected in low levels in normal melanocytes while PKC-ı was not detected. We also report that PKC-ı and PKC- $\zeta$ are overexpressed in SK-MEL-2 malignant melanoma cell line compared to undetectable levels of PKC-ı and low levels of PKC- $\zeta$ in PCS-200-013 normal melanocytes (15).

In the present study, we have investigated the effects of the novel aPKC specific inhibitors ACPD and DNDA on the proliferation, apoptosis, migration and invasion of two normal melanocyte cell lines (PCS-200-013 and MEL-F-NEO) and two malignant melanoma cell lines (SK-MEL-2 and MeWo). In this study, we showed that both inhibitors can decrease the levels of total and phosphorylated PKC- $\zeta$ and PKC-ı levels. We also found that both inhibitors can decrease the levels of both phosphorylated and total vimentin and increase E-cadherin levels which are associated with EMT. Treatment with inhibitors altered the levels of CD44, $\beta$-catenin, NF- $\kappa$ B p65, Par6, RhoA, AKT and PTEN whose roles are established in either cell survival or metastasis (16-18). Furthermore, we established that melanoma cells proliferate via aPKC/AKT/NF- $\kappa \mathrm{B}$ mediated pathway while inducing the EMT via $\mathrm{PKC}-\mathrm{\iota} / \mathrm{Par} 6 / \mathrm{RhoA}$ pathway. We report that $\mathrm{PKC}-\iota$ activates vimentin by phosphorylation. We also report that treatment with ACPD/DNDA induced apoptosis as shown by increasing caspase-3 levels, decreasing Bcl-2 levels and changes in Poly(ADP-ribose) polymerase (PARP) levels in addition to cell proliferation and downregulation of EMT in melanoma cells.

\section{Materials and methods}

Materials. ACPD (product no. R426911) was purchased from Sigma-Aldrich (St. Louis, MO, USA) and DNDA was obtained from the National Institute of Health (NIH; Bethesda, MD, USA). They were dissolved in sterile distilled water (vehicle) before use. Antibodies were purchased as follows. PKC-ı (cat. no. 610175) and Bcl-2 (cat. no. 610538) were from BD Biosciences (San Jose, CA, USA), PKC- $\zeta$ (cat. no. sc-17781), NF- $\mathrm{B}$ p65 (cat. no. sc-372-G) and caspase-3 (cat. no. sc-7272) from Santa Cruz Biotechnology (Santa Cruz, CA, USA), phospho PKC- $\zeta$ (Thr 410) (cat. no. PA5-17837), phospho PKC-ı (Thr 555) (cat. no. 44-968G), E-cadherin (cat. no. 701134), vimentin (cat. no. MA3-745) and myelin basic protein (MBP) (cat. no. PA1-10008) from Thermo Fisher Scientific (Waltham, MA, USA), phospho-vimentin (Ser39) (cat. no. 13614S), PTEN (cat. no. 9559S), phospho PTEN (Ser380) (cat. no. 9551), AKT (cat. no. 4691X), phospho AKT (Ser473) (cat. no. 4059S), PARP (cat. no. 9532) and cleaved-PARP (cat. no. 9185) from Cell Signaling Technology (Danvers, MA, USA). $\beta$-actinperoxidase (cat. no. A3854) from Sigma-Aldrich. CD44 (cat. no. ab97478), RhoA (cat. no. ab54835) and $\beta$-catenin (cat. no. ab16051) from Abcam (Cambridge, UK). Phospho-MBP (Thr 125) (cat. no. 05-429) from EMD Millipore (Billerica, MA, USA). Enhanced chemiluminescence solution (product no. 34080) was purchased from Pierce (Rockford, IL, USA). Dulbecco's phosphate-buffered saline without $\mathrm{Mg}^{2+}$ and $\mathrm{Ca}^{2+}$ (DPBS) (product no. D8537) and Trypsin-EDTA (ethylenediaminetetraacetic acid) solution (product no. T4049) were purchased from Sigma-Aldrich. WST-1 reagent for cell proliferation (cat. no. 11644807001) was purchased from Roche Diagnostics (Mannhelm, Germany). Basement membrane extraction (BME) and Calcein-AM solutions were purchased from Trevigen (Gaithersburg, MD, USA) and Molecular Probes (Eugene, OR, USA), respectively. Human small interfering RNA (siRNA) for PKC-ı (cat. no. SR303741) and for PKC- $\zeta$ (cat. no. 303747) were purchased from Origene Technologies Inc. (Rockville, MD, USA). Human recombinant proteins PKC-ı (PV3183), PKC- $\zeta$ (P2273) and MBP (MBS717422) were purchased from Thermo Fisher Scientific and MyBioSource (San Diego, CA, USA), respectively.

Database preparation and molecular docking. Database preparation was performed using the National Cancer Institute/Developmental Therapeutics Program (NCI/DTP) and molecular docking was performed using 'AutoDockTools' and 'AutoDock Vina' programs by selecting structural pockets in PKC-ı and PKC- $\zeta$ which were compatible with small drug like molecules. PKC-ı and PKC- $\zeta$ structural pockets were identified based on 'fpocket', a very fast open source protein pocket (cavity) detection system based on Voronoi Tessellation. The detailed procedure was performed as described in Pillai et al (19).

Cell culture. PCS-200-013, SK-MEL-2 and MeWo cell lines were purchased from the American Type Tissue Culture Collection (ATCC; Rockville, MD, USA) and MEL-F-NEO cell line was purchased from Zen-Bio, Inc. (Research Triangle Park, NC, USA). Furthermore, cells were cultured at $37^{\circ} \mathrm{C}$ and $5 \% \mathrm{CO}_{2}$.

Dermal cell basal medium (PCS-200-030) with melanocyte growth kit (PCS-200-042) were used for PCS-200-013 and melanocyte growth medium (MEL-2) were used for MEL-F-NEO cell culturing according to the respective instruction manual. Eagle's minimum essential media (EMEM) $(90 \%$ $\mathrm{v} / \mathrm{v})$ with fetal bovine serum (FBS) $(10 \% \mathrm{v} / \mathrm{v})$ and penicillin $(5 \mu \mathrm{g} / \mathrm{ml})$ were used for SK-MEL-2 and MeWo cell culturing. All cell lines were seeded and grown as monolayers in T25 or T75 flasks.

PKC activity assay. PKC activity assay was conducted by monitoring the phosphorylation of myelin basic protein (MBP) $(0.025 \mathrm{mg} / \mathrm{ml})$, a known substrate for PKCs. The detailed procedure was performed as described in the study by Pillai et al (19) for both ACPD and DNDA on recombinant PKC-ı and PKC- $\zeta(0.01 \mu \mathrm{g} / \mu \mathrm{l})$ using a series of inhibitor concentrations $(0-10 \mu \mathrm{M})$. Samples then fractionated by SDS-PAGE 
and immunoblotted. Kinase activity was calculated based on the densitometry values of western blots (WB).

Inhibition of expression of $P K C-\iota$ and $P K C-\zeta$ with siRNA. SK-MEL-2 and MeWo cells $\left(4 \times 10^{4}\right)$ were cultured in T25 flasks and treated with either siRNA $(20 \mathrm{nM})$ for PKC-ı or PKC- $\zeta$ or scrambled siRNA after $24 \mathrm{~h}$ post-plating time and incubated for $48 \mathrm{~h}$. Detailed procedure was performed as described in the study by Win and Acevedo-Duncan (20).

Inhibitor dose response curves for cell viability. PCS-200-013, MEL-F-NEO, SK-MEL-2 and MeWo cells $\left(4 \times 10^{4}\right)$ were cultured in T25 flasks and treated with either an equal volume of sterile water (vehicle control) or ACPD or DNDA (0.1-3.5 $\mu \mathrm{M})$. Additional doses of sterile water or ACPD or DNDA were supplied every $24 \mathrm{~h}$ during a 3 -day incubation period and cells were subsequently lifted using TrypsinEDTA solution $(1.5 \mathrm{ml} /$ flask $)$ and neutralized with the equal volume of media. Subsequently, live cells were counted using the Scepter, an automated cell counter from Millipore (Billerica, MA, USA) at 24-h intervals. Cell counts obtained from Scepter were compared with the counts obtained from the Cellometer Vision from Nexcelom Bioscience (Lawrence, MA, USA).

WST-1 assay for cell viability and cytotoxicity. Approximately $4 \times 10^{3}$ cells/well (PCS-200-013, MEL-F-NEO, SK-MEL-2 and MeWo) were cultured in a 96-well plate. After 24-h post plating time, fresh media were supplied (200 $\mu \mathrm{l} /$ well) and treated with either an equal volume of sterile water (vehicle control) or with the half maximal inhibitory concentration $\left(\mathrm{IC}_{50}\right)$ of ACPD $(2.5 \mu \mathrm{M})$ or DNDA $(2.5 \mu \mathrm{M})$. This $\mathrm{IC}_{50}$ was obtained based on the cell viability counts in the previous experiments. Additional doses were supplied every $24 \mathrm{~h}$ during a 3-day incubation period. At the end of the 3-day treatment, media were removed and fresh media $(100 \mu \mathrm{l})$ were added with 4-[3-(4-iodophenyl)-2-(4-nitropheny))-2H-5-tetrazolio]-1,3benzene disulfonate (WST-1) reagent $(10 \mu \mathrm{l})$ to each well. The absorbance was measured at $450 \mathrm{~nm}$ for every $1 \mathrm{~h}$ up to 6-10 h using the Synergy HT microplate reader from BioTek Instruments Inc. (Winooski, VT, USA).

\section{Assays for cell migration and invasion}

Wound healing assay. The detailed procedure was performed for SK-MEL-2 and MeWo cells as described by O'Connell et al (21). Cells were treated with either sterile water or ACPD or DNDA to achieve the final concentration of $2.5 \mu \mathrm{M}$ and plates were incubated at $37^{\circ} \mathrm{C}$ and $5 \% \mathrm{CO}_{2}$. Photographs of wound closure were taken utilizing a Motic AE31E microscope (x40 magnification) at 24-h intervals for 4 days.

Basement membrane extract (BME) invasion assay (Boyden chamber assay). This in vitro invasion assay was performed for SK-MEL-2 and MeWo cells as described by O'Connell et al (21). BME (0.5X) was used instead of Matrigel. Crystal violet $(0.5 \%)$ was used to stain the cells adhered to the bottom of the lower chamber in order to visualize the inhibition of invasion. Images of the stained cells were taken from Motic AE31E microscope (x40 magnification).
Immunoprecipitation and western blot analysis. Approximately $1 \times 10^{5}$ cells (SK-MEL-2 and MeWo) were cultured in T75 flasks and $24 \mathrm{~h}$ post-plating, fresh media were supplied and cells were treated with either an equal volume of sterile water or ACPD or DNDA $(2.5 \mu \mathrm{M})$. Additional doses were supplied every $24 \mathrm{~h}$ during a 3 -day incubation period. Cells were then lifted using Trypsin and cell lysate were collected either with cell lysis buffer (cat. no. C7027; Invitrogen) or IP lysis buffer (cat. no. 87788; Thermo Fisher Scientific). The WB and immunoprecipitation were performed as described in the study by Win et al (22) and samples were then fractionated by SDS-PAGE and immunoblotted.

Densitometry. The intensity of each WB band was measured using 'AlphaView' software for 'Fluorchem' systems developed by ProteinSimple (San Jose, CA, USA) in which the background intensity was subtracted from the intensity of each band to obtain the corrected intensity of the proteins.

Statistical analysis. All data are presented as mean \pm SD. Statistical analysis was performed with one or two-way ANOVA followed by Tukey's HSD test as multiple comparisons tests using the 'VassarStats' web tool for statistical analysis. $\mathrm{P} \leq 0.05$ or $\mathrm{P} \leq 0.01$ indicated statistical significance.

\section{Results}

Specific binding of ACPD and DNDA to aPKCs. To establish the therapeutic potential of aPKCs, ACPD (Fig. 1A) and DNDA (Fig. 1B) were identified based on molecular docking (MD). Approximately $3 \times 10^{5}$ drug like organic compounds (molecular weight $<500 \mathrm{~g} / \mathrm{mol}$ ) in NCI/DTP, were screened by positioning them in the structural pockets of PKC-ı and PKC- $\zeta$ and then scored based on predicted polar and non-polar interactions. ACPD was found to interact with amino acid residues Gln 469, Ile 470, Lys 485 and Leu 488 of the catalytic domain of PKC-ı (Fig. 1C) and Arg 265, Pro 267, Asp 269 and Lys 290 of the catalytic domain of PKC- $\zeta$ (Fig. 1D). DNDA interacts with amino acid residues of Asp 339, Asp 382, Leu 385 and Thr 395 of the catalytic domain of PKC-ı (Fig. 1E) and Asp 337, Asp 380, Leu 383 and Thr 393 of the catalytic domain of PKC- $\zeta$ (Fig. 1F). Approximately $-7 \mathrm{kcal} / \mathrm{mol}$ docking score was obtained for ACPD and DNDA separately for PKC-ı and PKC- $\zeta$ for 4 different pockets. Sixteen pockets were identified and tested for both PKC-ı and PKC- $\zeta$ separately and all the pockets that scored above $-6.5 \mathrm{kcal} / \mathrm{mol}$ were rejected to identify these specific binding sites of the inhibitors. The results here suggest that both ACPD and DNDA interact with PKC-ı and $\mathrm{PKC}-\zeta$ in a fairly equal manner.

Specific kinase activities of ACPD and DNDA. Determination of specific activity of inhibitors was essential since over $70 \%$ similarity is observed in the primary structures of PKC- 1 and PKC- $\zeta$ catalytic domains $(5,23,24)$. Specificity of ACPD was previously reported as it inhibits both PKC-ı and PKC- $\zeta$ without affecting other PKC isoforms (25). Additionally, ACPD does not inhibit other kinases such as AMPK, Akt2, FGFR1/2/3/4, mTOR, GSK3 $\beta$, IRAK1/4, JAK1/2, MEK1, ERK1/2, JNK1/2, PKA, Src, ROCK2 and PI3K (26,27). This confirms our finding of ACPD in molecular docking experi- 
$\mathbf{A}$<smiles>CC(=O)C1C(=O)CCC1=O</smiles><smiles>Nc1c(S(=O)(=O)O)cc2cc(S(=O)(=O)O)ccc2c1N</smiles>
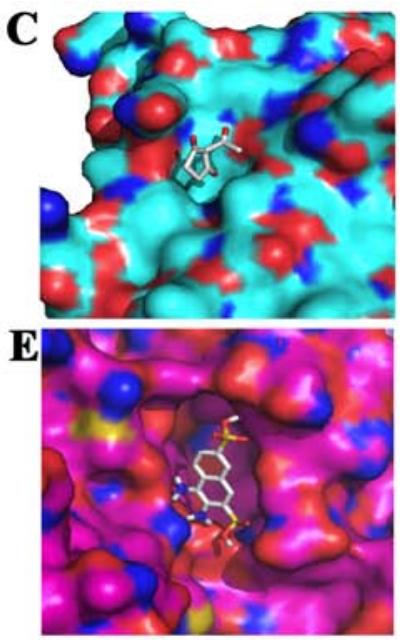
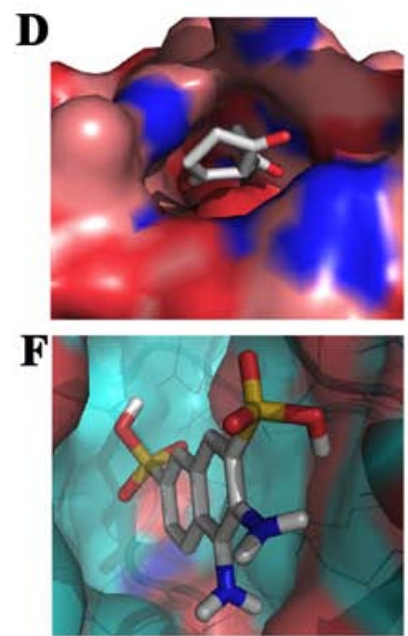

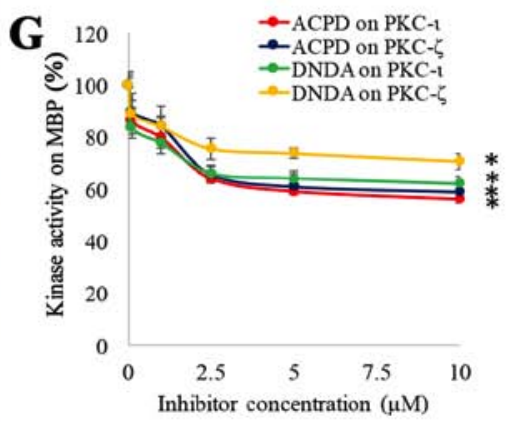

Figure 1. Structures and molecular docking of ACPD and DNDA. Chemical structures of (A) ACPD and (B) DNDA, molecular docking (MD) of ACPD on PKC-ı (C) and PKC- $\zeta$ (D) and MD of DNDA on PKC-ı (E) and PKC- $\zeta$ (F) are shown. Molecular weights of ACPD and DNDA are 140.14 and 318.32 g/mol, respectively. ACPD interacts with amino acid residues of 469-488 of the catalytic domain of PKC-ı and amino acid residues of 265-290 of the catalytic domain of PKC- $\zeta$. DNDA interacts with amino acid residues of 339-395 of the catalytic domain of PKC-ı and amino acid residues of 337-393 of the catalytic domain of PKC- $\zeta$. (G) Represents the effect of ACPD and DNDA on PKC-ı and PKC- $\zeta$ activity. Recombinant active PKC- $\zeta$ or PKC-ı were incubated with myelin basic protein in the presence or absence of ACPD and DNDA $(0.1-10 \mu \mathrm{M})$ and percentage kinase activity was plotted against inhibitor concentration $(\mathrm{N}=3)$.
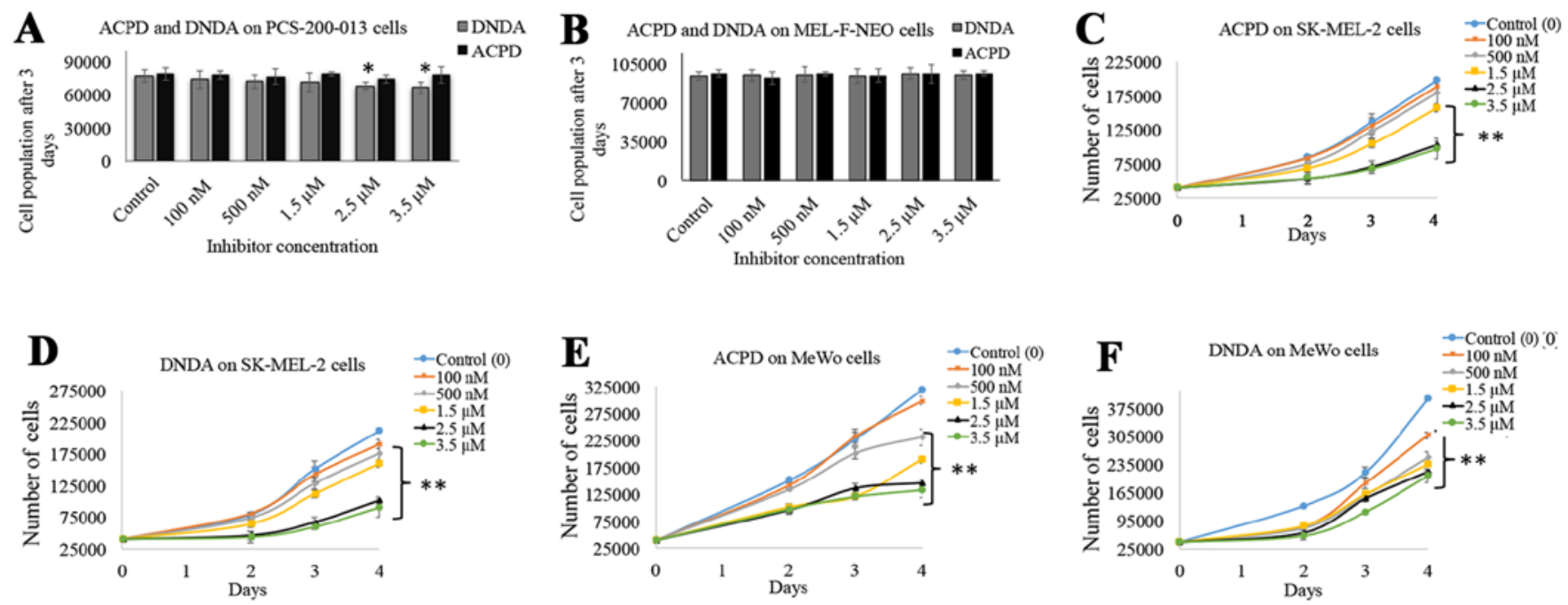

Figure 2. Effects of aPKC inhibitors (ACPD and DNDA) on cell proliferation of normal melanocytes and malignant melanoma cells. Results depict the effect of ACPD and DNDA on PCS-200-013 (A) and on MEL-F-NEO (B), ACPD on SK-MEL-2 (C), DNDA on SK-MEL-2 (D), ACPD on MeWo (E) and DNDA on MeWo (F). Approximately $4 \times 10^{4}$ were cultured in T25 flasks and treated with either equal volume of sterile water (control) or ACPD or DNDA (0.1-3.5 $\left.\mu \mathrm{M}\right)$. Additional doses of sterile water or ACPD or DNDA were supplied every $24 \mathrm{~h}$ during a 3-day incubation period. Subsequently, cells were lifted and counted. Cell count for PCS-200-013 and MEL-F-NEO cells were only obtained for 3 days due to longer doubling time. The two malignant cell lines (SK-MEL-2 and $\mathrm{MeWo}$ ) were quantified by counting the viable cells at 24 -h intervals. $\mathrm{N}=3$ experiments were performed for each cell line and mean \pm SD are plotted. Statistical significance is indicated by asterisks as ${ }^{*} \mathrm{P}<0.05$ and ${ }^{* *} \mathrm{P}<0.01$.

ments that it did not show significant binding to other kinases apart from PKC-ı and PKC- $\zeta$. We conducted kinase activity assay (in vitro) of ACPD and DNDA in order to confirm our virtual screening data. Kinase activities of ACPD and DNDA (Fig. 1G) were determined for a series of concentrations (0.1-10 $\mu \mathrm{M})$ using recombinant active PKC-ı or PKC- $\zeta$ in the presence of MBP which is a well-known substrate for PKCs (28). Both compounds demonstrated significant inhibitions for both PKC-ı and PKC- $\zeta$ under all tested concentrations. Both compounds showed maximum inhibition for their $10 \mu \mathrm{M}$ solutions as ACPD on PKC-ı as $44 \%$ (P $\leq 0.05)$, ACPD on $\mathrm{PKC}-\zeta$ as $41 \%(\mathrm{P} \leq 0.05)$, DNDA on PKC- $-\iota$ as $38 \%(\mathrm{P} \leq 0.05)$ and DNDA on PKC- $\zeta$ as $29 \%(\mathrm{P} \leq 0.05)$. This confirms that DNDA also shows specific inhibition on PKC-ı and PKC- $\zeta$ in addition to ACPD. These kinase activity data confirm our virtual screening data.

Inhibitor dose-response curves. Dose curves for ACPD and DNDA were obtained to investigate the effects on cell proliferation of normal and malignant cell lines over a wide range of concentration. ACPD and DNDA did not show a significant effect on PCS-200-013 (Fig. 2A) except 2.5 and 3.5 $\mu$ M DNDA treatments in which significant inhibitions were achieved $(\mathrm{P} \leq 0.05)$. Similarly, neither inhibitor showed a significant 

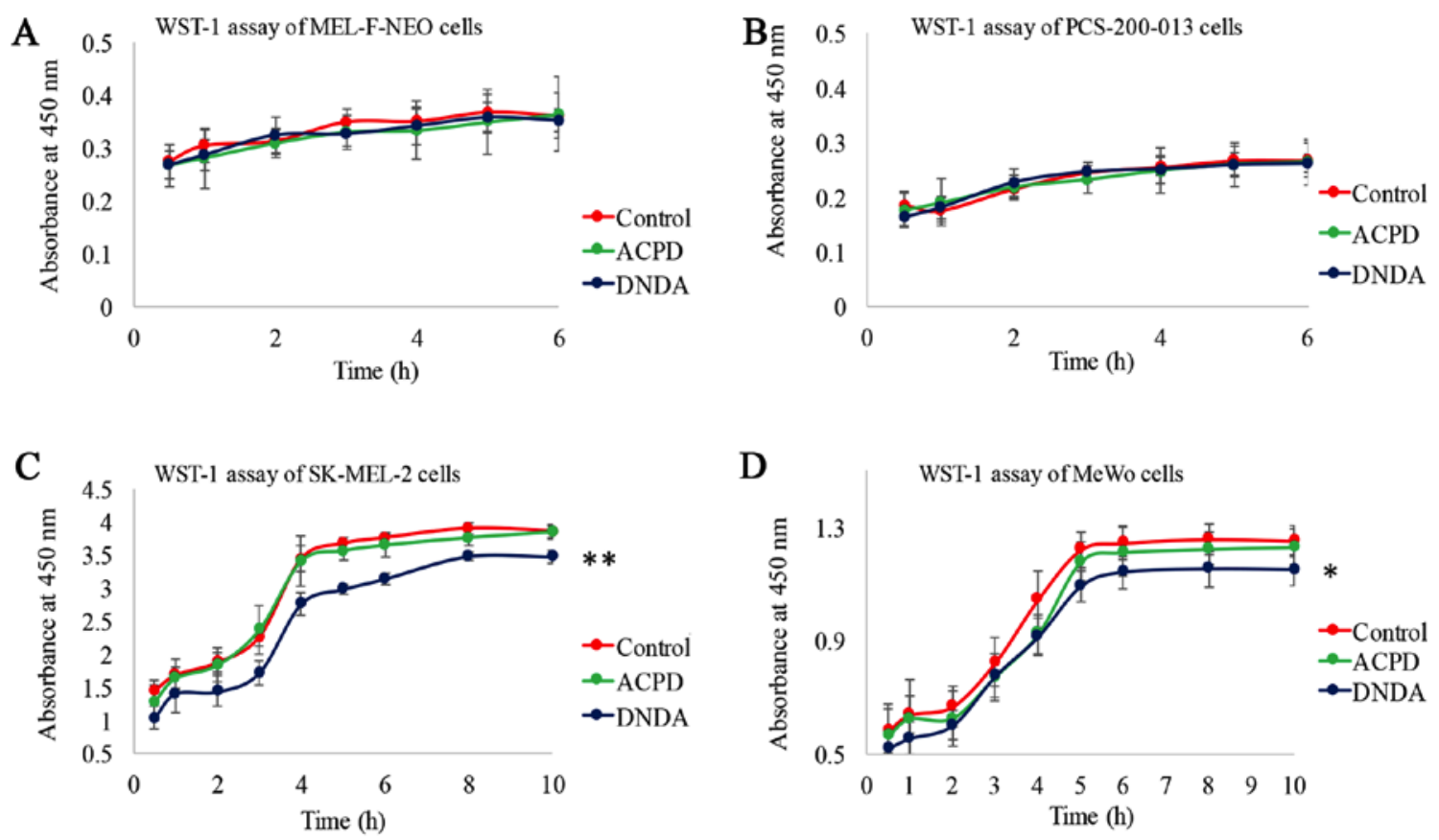

Figure 3. Effects of aPKC inhibitors from WST-1 assay for cell viability and cytotoxicity. Cell proliferation was measured using WST-1 assay for (A) MEL-F-NEO, (B) PCS-200-013, (C) SK-MEL-2 and (D) MeWo. The absorbance at $450 \mathrm{~nm}$ is due to production of water soluble formazan and was measured as a function of time. The absorbance is directly proportional to the number of cells. Experimental concentrations for both ACPD and DNDA were $2.5 \mu \mathrm{M}$ and the absorbance at $450 \mathrm{~nm}$ against time is plotted. Experiments $(\mathrm{N}=3)$ were performed for each cell line and mean $\pm \mathrm{SD}$ are plotted. ${ }^{*} \mathrm{P}<0.05$ and ${ }^{* *} \mathrm{P}<0.01$ indicate statistical significance.

inhibition for MEL-F-NEO normal melanocyte cells (Fig. 2B). Both inhibitors significantly decreased cell proliferation of SK-MEL-2 and MeWo upon increasing the concentrations. ACPD decreased proliferation by $20 \%$ for $1.5 \mu \mathrm{M}(\mathrm{P} \leq 0.01)$, $48 \%$ for $2.5 \mu \mathrm{M}(\mathrm{P} \leq 0.01)$ and $51 \%$ for $3.5 \mu \mathrm{M}(\mathrm{P} \leq 0.01)$ (Fig. 2C) and DNDA decreased $24 \%$ for $1.5 \mu \mathrm{M}(\mathrm{P} \leq 0.01), 52 \%$ for $2.5 \mu \mathrm{M}(\mathrm{P} \leq 0.01)$ and $57 \%$ for $3.5 \mu \mathrm{M}(\mathrm{P} \leq 0.01)$ (Fig. $2 \mathrm{D})$ in the SK-MEL-2 cell line. ACPD decreased proliferation by $41 \%$ for $1.5 \mu \mathrm{M}(\mathrm{P} \leq 0.01), 54 \%$ for $2.5 \mu \mathrm{M}(\mathrm{P} \leq 0.01)$ and $58 \%$ for $3.5 \mu \mathrm{M}(\mathrm{P} \leq 0.01)$ (Fig. 2E) and DNDA decreased proliferation by $41 \%$ for $1.5 \mu \mathrm{M}(\mathrm{P} \leq 0.01), 46 \%$ for $2.5 \mu \mathrm{M}(\mathrm{P} \leq 0.01)$ and $48 \%$ for $3.5 \mu \mathrm{M}(\mathrm{P} \leq 0.01)$ (Fig. $2 \mathrm{~F})$ in the MeWo cell line. These results suggest that both inhibitors can effectively decrease the cell population while not having a significant effect on normal melanocytes. Based on these results the $\mathrm{IC}_{50}$ of ACPD and DNDA for both drugs were found to be $\sim 2.5 \mu \mathrm{M}$ and this concentration was used in later experiments.

WST-1 assay for cell viability and cytotoxicity. To determine the in vitro cytotoxicity of ACPD and DNDA on normal and malignant cell lines, we performed a WST-1 assay. The measured absorbance at $450 \mathrm{~nm}$ is directly proportional to the number of viable cells present. Viable cells produce a watersoluble formazan with WST-1 as a result of their mitochondrial dehydrogenase activity. WST-1 assay is preferred over the 3-(4,S-dimethyl-2-thiazolyl)-2,5-diphenyl-2H-tetrazolium bromide (MTT) test. This is because MTT requires acidic isopropanol to dissolve formazan, providing an additional toxicity to cells (29). Neither inhibitor showed a significant effect on normal melanocyte cells (Fig. 3A and B). ACPD did not show a significant effect on either malignant cell line but DNDA showed a significant decrease in absorption on

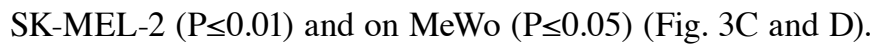
Results indicate that both ACPD and DNDA appeared to be cytostatic thereby inhibiting cell growth and proliferation. DNDA showed a mild cytotoxicity to both melanoma cell lines in addition to its cytostatic nature.

Wound healing assay. Wound healing assay was performed to investigate the effect of ACPD and DNDA on malignant melanoma cell migration in vitro. Wound healing assay is commonly used to investigate in vitro migration of cancer cells (30). Photographs for each cell line are compared as 'day 0' (starting point) and 'day 3' or 'day 4' for both malignant cell lines (Fig. 4A). Cells treated with ACPD $2.5 \mu \mathrm{M}$ and DNDA $2.5 \mu \mathrm{M}$ were compared with their respective controls. The areas of the scratch (wound) were calculated and compared to determine the statistical significance (Fig. 4B). We found that both inhibitors significantly reduce the wound closure $(\mathrm{P} \leq 0.01)$ of both cell lines compared to respective controls. Results suggested that both drugs are equally effective in reducing cell migration in vitro.

BME invasion assay. This invasion assay was performed to investigate the effect of ACPD and DNDA on malignant melanoma cell invasion in vitro. Although it is similar to Boyden chamber assay, it avoids scraping off the Matrigel and staining to assess the number of migrated cells through the filter. Hence, the method carries less human error compared to a conventional Boyden chamber assay (21). Migrated cells were stained with a fluorescent marker; Calcein-AM. Live cells cleave the ester (AM) of the molecule in order to produce fluorescence. Thus, the amount of fluorescence accumulate in the bottom chamber is proportional to the number of invaded 


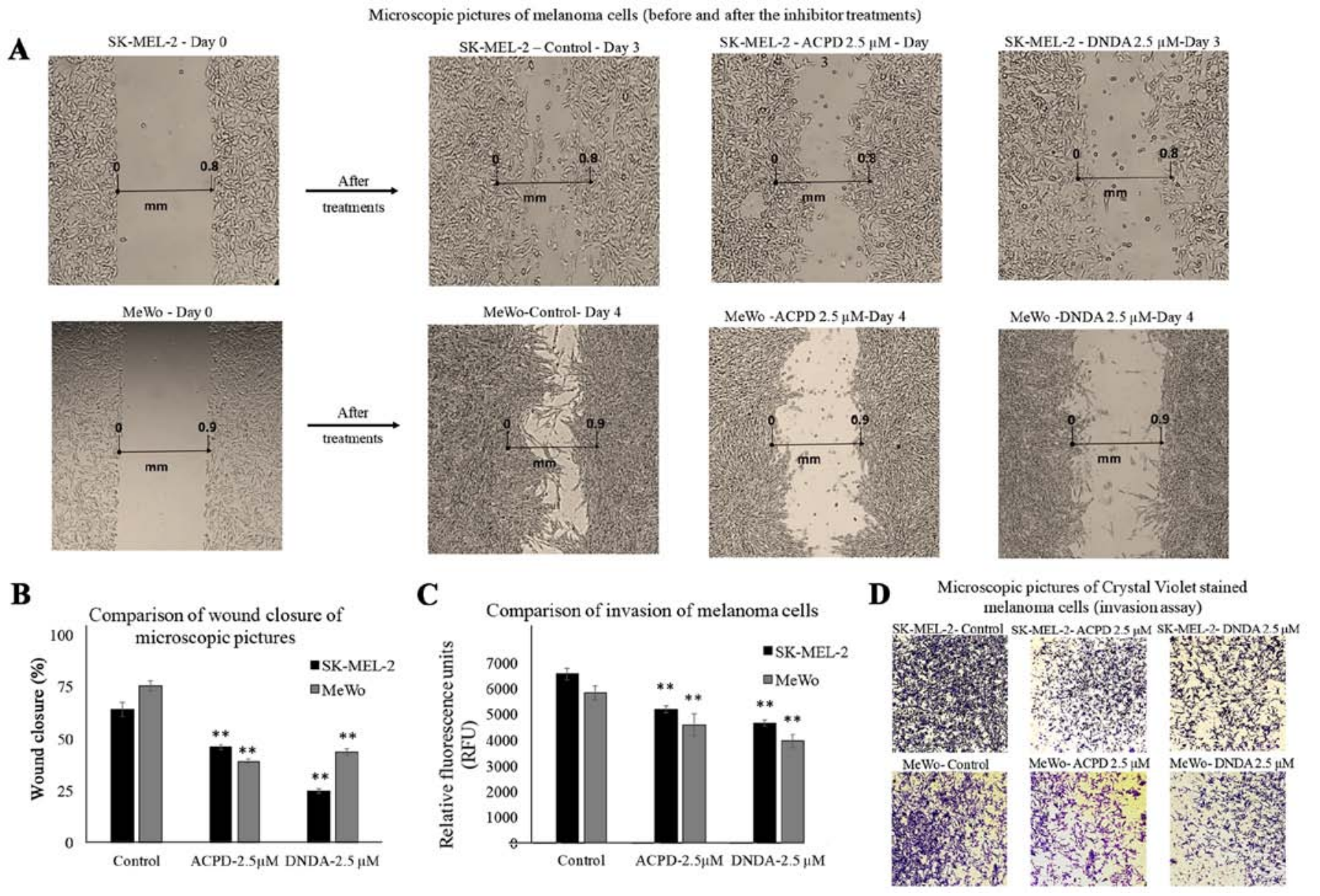

Figure 4. ACPD and DNDA decreases melanoma cell migration and invasion. (A and B) The effect of aPKC inhibitors (2.5 $\mu \mathrm{M}$ of ACPD and DNDA) on melanoma cell migration in wound healing assay and (C and D) represent the effect of inhibitors on melanoma cell invasion in Boyden chamber assay with basement extract. In wound healing assay, microscopic photographs of scratches on cells at the beginning (day 0) were compared with the images taken after 3 or 4 days. The effect of inhibitors are shown (A) compared to their control for both ACPD and DNDA. Experiments (N=3) were performed for each cell line and randomly picked photographs are shown. (B) Represents a comparison of calculated percent wound closure for the photographs taken. For Boyden chamber assay (C), relative fluorescence unit (RFU) values were reported after 2-h exposure of invaded cells with Calcein-AM, as a comparison of control and inhibitors (2.5 $\mu \mathrm{M}$ ACPD and DNDA) treated samples by subtracting the blanks (no cells). (D) A visual representation of crystal violet stained cells which adhered to the bottom of the lower chamber after the invasion. Mean $\pm \mathrm{SD}$ are plotted in $\mathrm{B}$ and $\mathrm{C}$. ${ }^{* *} \mathrm{P}<0.01$ indicates statistical significance.

cells. The relative fluorescent units (excitation at 485 and emission at $528 \mathrm{~nm}$ ) after $2 \mathrm{~h}$ of exposure were reported for inhibitor treatments for both SK-MEL-2 and MeWo cell lines compared to controls (Fig. 4C). Invasion was significantly reduced $(\mathrm{P} \leq 0.05)$ by 24 and $21 \%$ in $\mathrm{ACPD}(2.5 \mu \mathrm{M})$ treated SK-MEL-2 and MeWo cells compared to its control. In DNDA $(2.5 \mu \mathrm{M})$ treated samples, the invasion was significantly reduced $(\mathrm{P} \leq 0.05)$ by $32 \%$ in both SK-MEL-2 and MeWo cell lines compared to its control. Invaded cells on the bottom chamber were stained with crystal violet and images were taken in randomly chosen fields as the visual representation of the invasion assay (Fig. 4D).

Effect of ACPD and DNDA on aPKC levels in malignant melanoma. Before analyzing the levels of aPKCs in inhibitor treated melanoma cell lines using WB, we compared the protein levels of aPKCs, E-cadherin, vimentin and Bcl-2 in MEL-F-NEO normal melanocytes at $100 \%$ confluency and $50 \%$ confluency. PKC- - and vimentin were not detected at either confluency level in MEL-F-NEO cells. PKC- $\zeta$, E-cadherin and Bcl-2 levels were found to be higher in 50\% confluency level compared to $100 \%$ confluency (Fig. 5A). $\beta$-actin was used as the internal control to ensure that equal amounts of proteins were loaded in each lane in the SDS-PAGE.

WB were performed to investigate the effect of ACPD and DNDA on the expression of aPKCs on malignant melanoma (Fig. 5B). ACPD significantly reduced the PKC-ı level by 43 and by $31 \%$ of pPKC-ı in SK-MEL-2 cell line and by $46 \%$ of PKC- $\iota$ and $26 \%$ of pPKC- $\iota$ in MeWo cells. DNDA significantly decreased the levels of PKC-ı by 52\%, pPKC-ı by 33\% in SK-MEL-2 and by $27 \%$ of PKC- $\iota$ and pPKC- - by $20 \%$ in MeWo cells. Also, ACPD significantly reduced the PKC- $\zeta$ level by 42 and by $29 \%$ of pPKC- $\zeta$ in SK-MEL-2 cell line and by $42 \%$ of PKC- $\zeta$ and $23 \%$ of pPKC- $\zeta$ in MeWo cells. DNDA significantly reduced the levels of PKC- $\zeta$ by 33\%, pPKC- $\zeta$ by only $17 \%$ in SK-MEL- 2 and by $60 \%$ of PKC- $\zeta$ and pPKC- $\zeta$ by $29 \%$ in MeWo. All values (percent) were calculated and compared to their respective control in WB (Fig. 5B; densitometry analysis) and significance was indicated as $P \leq 0.05$. $\beta$-actin was used as the internal control to ensure that equal amounts of proteins were loaded in each lane in the SDS-PAGE. 
$\mathbf{A}$

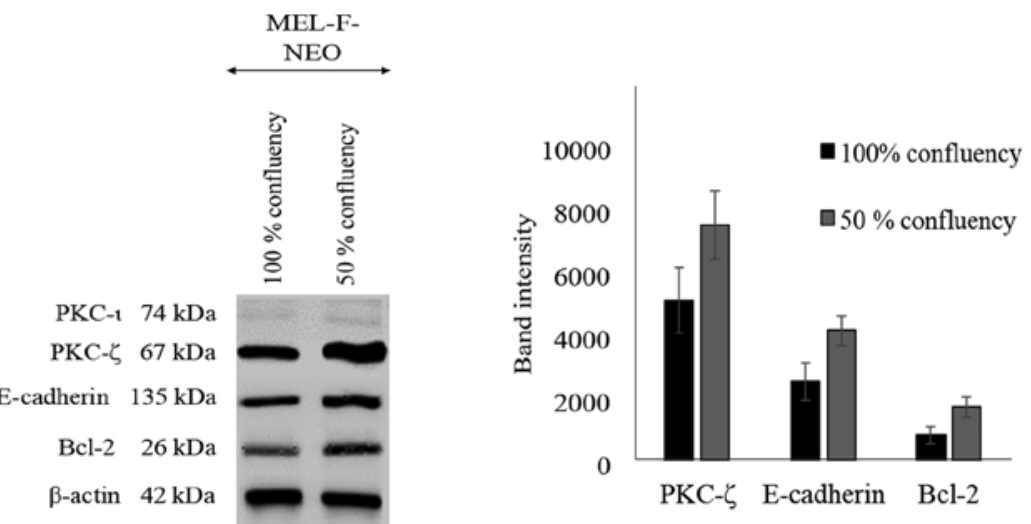

B

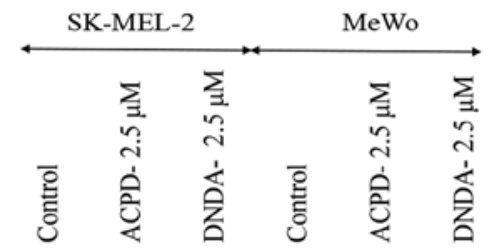

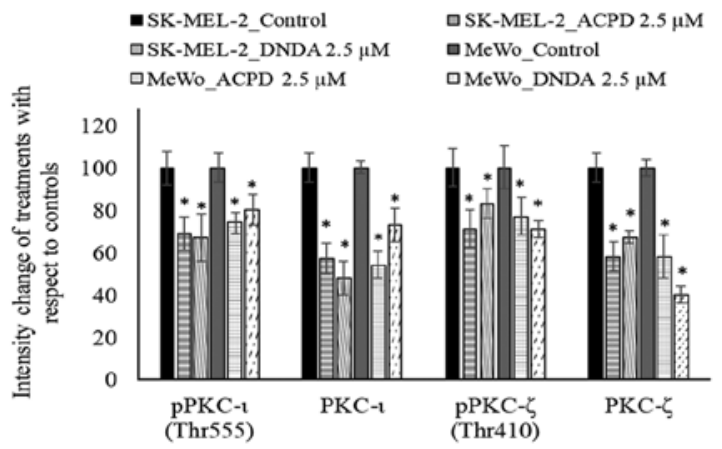

$\mathbf{C}$
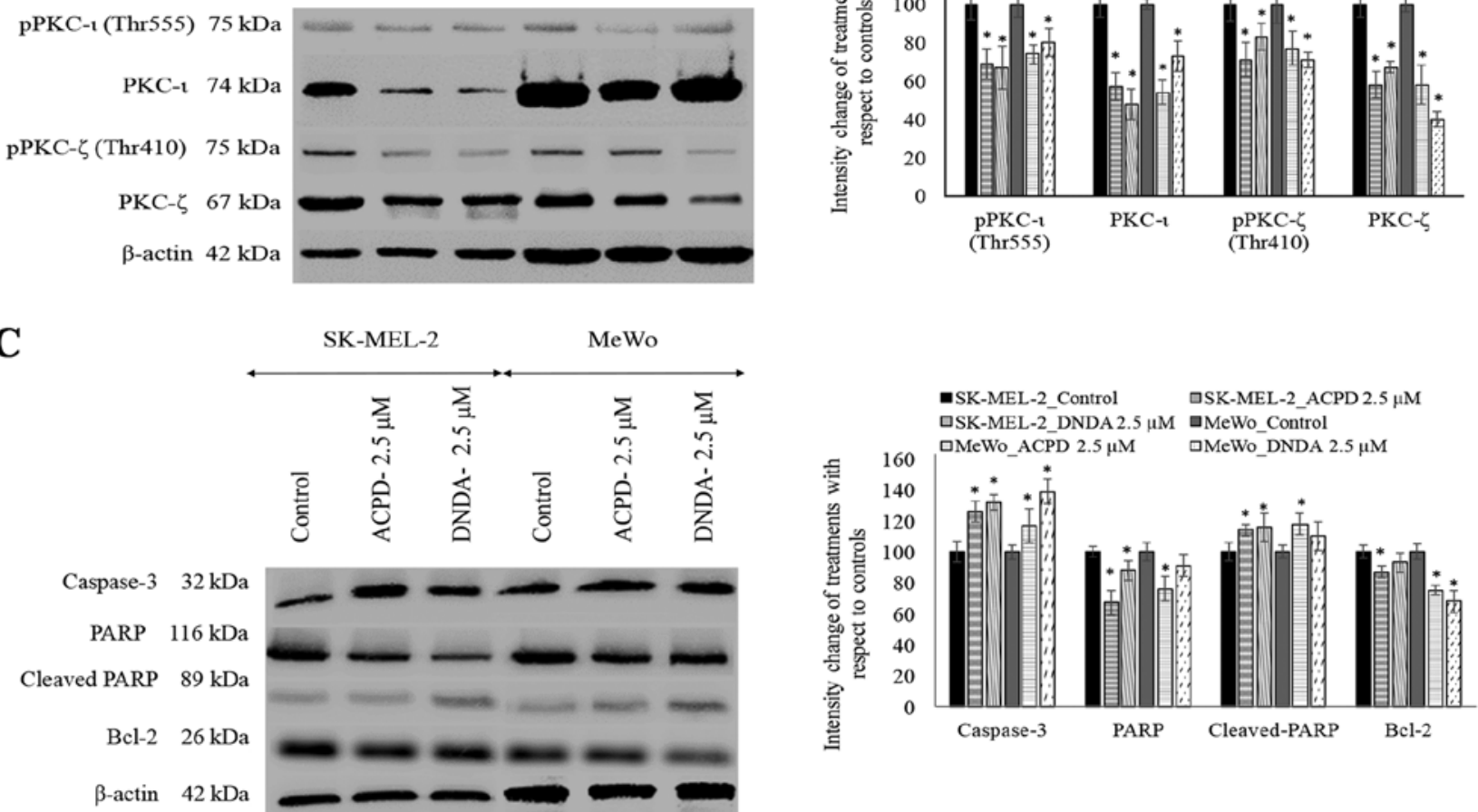

Figure 5. Western blots of aPKC expression in normal melanocytes and the effects of ACPD and DNDA on aPKC expression and apoptosis on malignant melanoma cells. (A) The western blots and densitometry values of expression of PKC- $\iota$, PKC- $\zeta$, E-cadherin and Bcl-2 in MEL-F-NEO normal melanocytes examined at 50 and $100 \%$ confluency levels. (B) The expression of phosphorylated PKC-ı, total PKC-ı, phosphorylated PKC- $\zeta$ and total PKC- $\zeta$ and (C) represents the protein expression of selected apoptotic markers (caspase-3, cleaved PARP, total PARP and Bcl-2) for the ACPD and DNDA (2.5 $\mu \mathrm{M})$ treated malignant melanoma cell lines (SK-MEL-2 and MeWo) after the end of 3rd day of treatments with respect to their controls. Densitometry bar graphs for $(\mathrm{B}$ and $\mathrm{C})$ are shown as the percentage change of the treated samples with respect to their controls and mean $\pm \mathrm{SD}$ are plotted. A total of $40 \mu \mathrm{g}$ of protein was loaded into each well and $\beta$-actin was used as the loading control in each western blot analysis. Experiments $(\mathrm{N}=3)$ were performed.

Effect of ACPD and DNDA on apoptosis of malignant melanoma. Since both inhibitors significantly inhibit melanoma cell proliferation, we tested the potential of the inhibitors on inducing apoptosis (Fig. 5C). Caspase-3 levels significantly increased by 26 and $17 \%$ in ACPD treated SK-MEL-2 and MeWo cells, respectively. Caspase-3 levels significantly increased by 32 and 39\% in DNDA treated SK-MEL-2 and MeWo cells, respectively. PARP levels significantly decreased by 33 and by $24 \%$ in ACPD treated SK-MEL- 2 and MeWo cells, respectively, while cleaved-PARP levels significantly increased by 14 and 18\%, respectively. In DNDA treated samples, PARP levels significantly decreased by 12 and by $9 \%$ in SK-MEL-2 and MeWo cells, respectively, while cleaved-PARP levels significantly increased by 16 and $10 \%$, respectively. Similarly, Bcl-2 levels significantly decreased by 13 and by $25 \%$ in ACPD treated SK-MEL-2 and MeWo cells, respectively, while in DNDA treated cells Bcl-2 levels decreased by 7 and by $32 \%$ in SK-MEL-2 and MeWo cells, respectively. All values (percent) were calculated compared to their respective control in WB (Fig. 5C; densitometry analysis) 

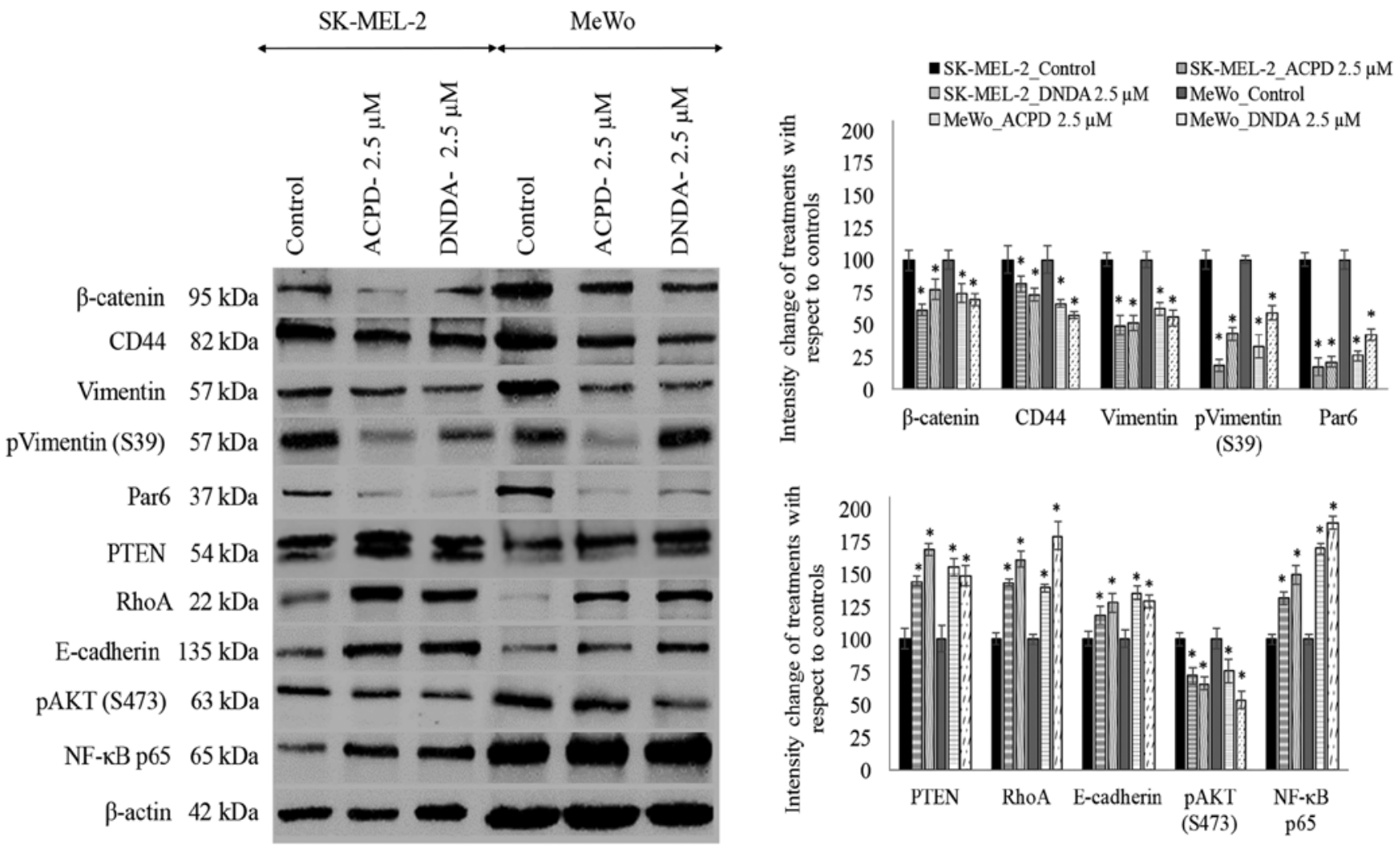

Figure 6. Effect of ACPD and DNDA on EMT signaling pathways. Expression of the protein levels of $\beta$-catenin, CD44, vimentin, phosphorylated vimentin, Par6, PTEN, RhoA, E-cadherin, phosphorylated AKT and NF-kB p65 for the ACPD and DNDA treated malignant melanoma cell lines (SK-MEL-2 and MeWo) are shown after the end of 3rd day of treatments with respect to their controls. Densitometry bar graphs are shown as the percentage change of the treated samples with respect to their controls and mean $\pm \mathrm{SD}$ are plotted. A total of $40 \mu \mathrm{g}$ of protein was loaded into each well and $\beta$-actin was used as the loading control in each western blot analysis. Three experiments were performed.

and significance are indicated as $\mathrm{P} \leq 0.05$. $\beta$-actin was used as the internal control to ensure that equal amounts of proteins were loaded in each lane in the SDS-PAGE.

Effect of ACPD and DNDA on signaling pathways and EMT. As shown in Fig. 6, we also investigated the effects of ACPD and DNDA on EMT by studying the signaling cascades crucial for cancer cell proliferation, survival, migration and invasion. The purpose of the analysis was to obtain a better understanding of how aPKCs are involved in the progression of melanoma. We tested the effects of ACPD and DNDA on proteins $\beta$-catenin, CD44, vimentin, Par6, PTEN, RhoA, E-cadherin, AKT and NF- $\kappa$ B p65 to determine how Wnt signaling, NF- $\mathrm{KB}$ signaling and AKT signaling are affected by aPKC inhibitors during EMT stimulation.

$\beta$-catenin significantly decreased by 39 and $26 \%$ in ACPD treated SK-MEL-2 and MeWo cells, respectively compared to 23 and $31 \%$ downregulation in DNDA treated samples. CD44 also decreased significantly by 19 and $34 \%$ in ACPD treated SK-MEL-2 and MeWo cells, in comparison to 27 and $43 \%$ downregulation in DNDA treated samples. Vimentin levels significantly decreased by 51 and $38 \%$ in ACPD treated SK-MEL-2 and MeWo cells, respectively compared to 49 and $45 \%$ decreases in DNDA treated samples. E-cadherin levels increased significantly by 18 and $35 \%$ in ACPD treated SK-MEL-2 and MeWo cells, while there were 28 and $29 \%$ increases in DNDA treated samples. Notably, $\mathrm{NF}-\kappa \mathrm{B}$ p65 levels significantly increased by 31 and $69 \%$ in
ACPD treated SK-MEL-2 and MeWo cells, and there were 49 and $89 \%$ increases in DNDA treated samples. Phospho vimentin (S473) levels significantly decreased by 82 and $67 \%$ in ACPD treated SK-MEL-2 and MeWo cells, respectively, compared to 57 and $41 \%$ decreases in DNDA treated samples. Par6 levels significantly decreased by 83 and 74\% in ACPD treated SK-MEL-2 and MeWo cells, respectively compared to 79 and $58 \%$ decreases in DNDA treated samples. PTEN levels significantly increased by 44 and $55 \%$ in ACPD treated SK-MEL-2 and MeWo cells, respectively, compared to 68 and $48 \%$ increases in DNDA treated samples. RhoA levels significantly increased by 87 and $70 \%$ in ACPD treated SK-MEL-2 and MeWo cells, respectively, compared to 80 and $66 \%$ increases in DNDA treated samples. All values (percent) were calculated compared to their respective controls in WB (Fig. 6; densitometry analysis) and significance was indicated as $\mathrm{P} \leq 0.05$. $\beta$-actin was used as the internal control to ensure that equal amounts of proteins were loaded in each lane in the SDS-PAGE.

siRNA treatments for $P K C-\iota$ and $P K C-\zeta$. Both melanoma cell lines were treated with siRNA for PKC-ı and PKC- $\zeta$ to knock down the expression of said proteins and subsequently investigated the levels of protein expression for the proteins tested (Fig. 7). Scrambled siRNA was also used in addition to the control and there was no significant difference observed between the control and scrambled siRNA treatments for the said proteins. 

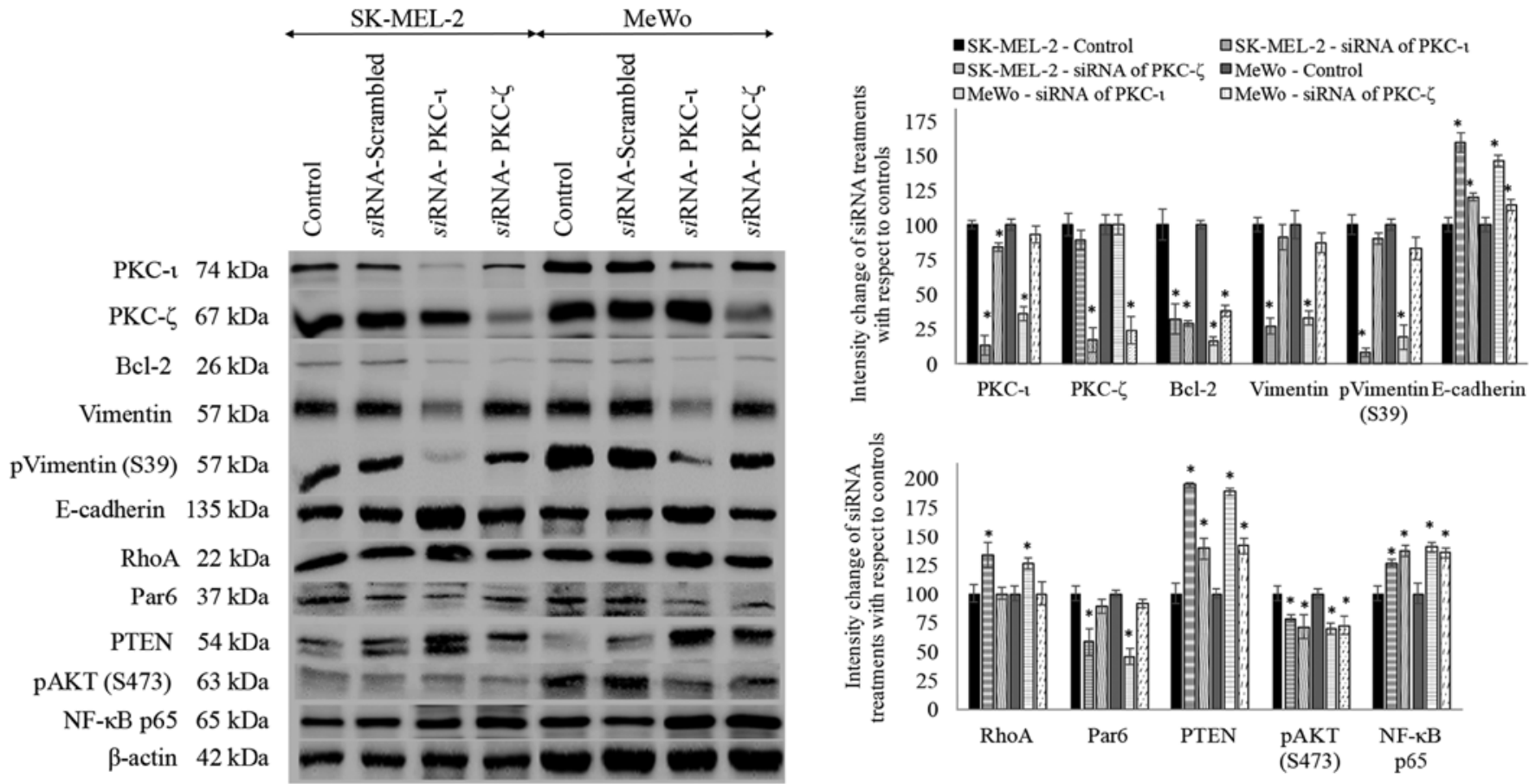

Figure 7. Effect of $s i$ RNA knockdown of the expression of PKC-ı and PKC- $\zeta$ and EMT signaling. Expression of the protein levels of PKC-ı, PKC- $\zeta$, Bcl-2, vimentin, phosphorylated vimentin, Par6, PTEN, RhoA, E-cadherin, phosphorylated AKT and NF- $\kappa$ B p65 for PKC-ı siRNA and PKC- $\zeta$ siRNA treated malignant melanoma cell lines (SK-MEL-2 and MeWo) are shown after the end of 2nd day of treatments with respect to their controls. Densitometry bar graphs are shown as the percentage change of the treated samples with respect to their controls and mean \pm SD are plotted. A total of $40 \mu \mathrm{g}$ of protein was loaded into each well and $\beta$-actin was used as the loading control in each western blot analysis. Three experiments were performed.

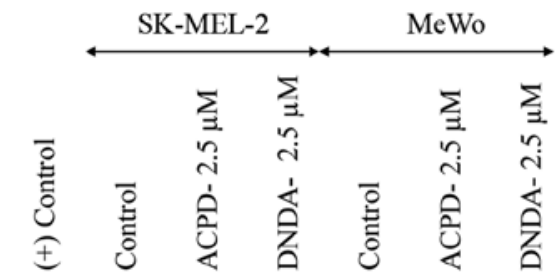

IP PKC-1, WB E-cadherin $135 \mathrm{kDa}$ IP PKC-1, WB CD44 $82 \mathrm{kDa}$ IP PKC-1, WB NF-kB p65 65 kDa

IP PKC-1, WB PKC-1 $74 \mathrm{kDa}$ IP PKC-1, WB Vimentin $57 \mathrm{kDa}$

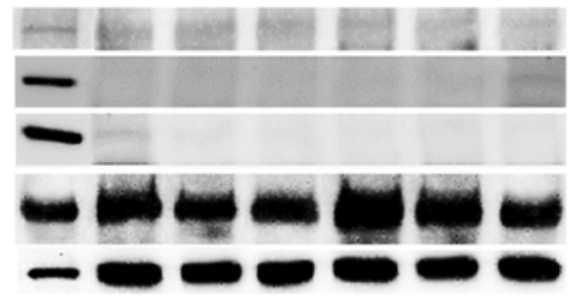

IP Vimentin, WB E-cadherin $135 \mathrm{kDa}$

IP Vimentin, WB PKC-1 $74 \mathrm{kDa}$

IP Vimentin, WB CD44 $82 \mathrm{kDa}$

IP Vimentin, WB Vimentin $57 \mathrm{kDa}$

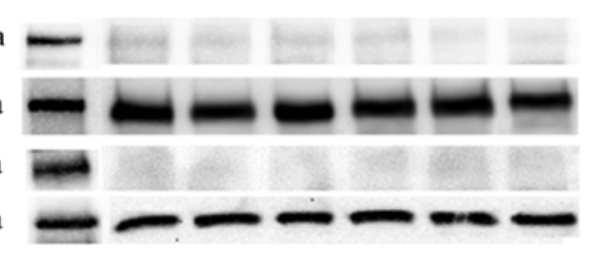

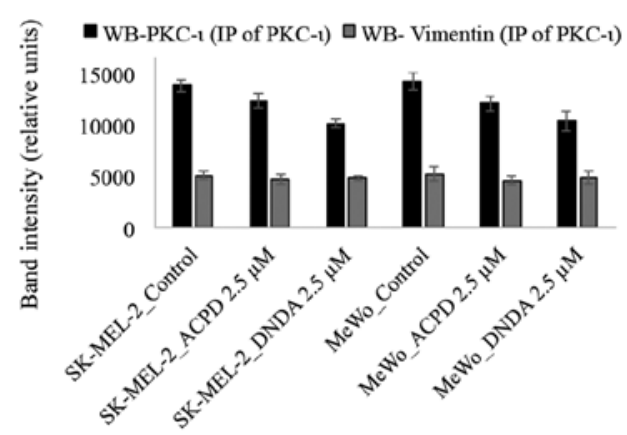

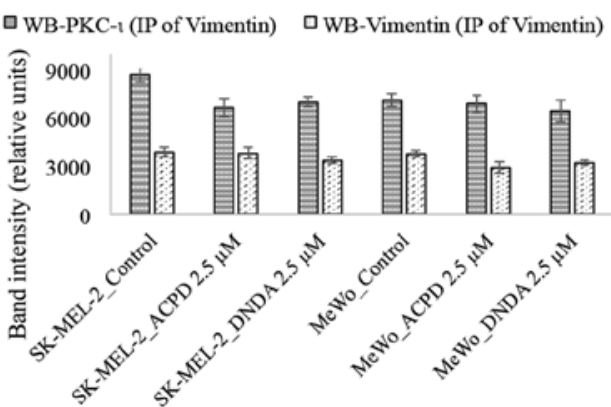

Figure 8. PKC-ı strongly associates with vimentin. Whole cell lysates (100 $\mu \mathrm{g})$ of malignant cells (Sk-Mel-2 and MeWo) were IP separately for PKC-ı and vimentin using specific antibodies. First column of the western blot analysis represents the (+) control which contained $40 \mu \mathrm{g}$ of MeWo whole cell extract, applied to ensure that bands appeared for the specific proteins in western blots. Western blots of PKC-ı IP showed an association with vimentin while no association was observed for E-cadherin, CD44 and NF- $\mathrm{kB}$ p65. Vimentin IP confirmed the association with PKC-ı the western blot while no association was observed with above mentioned proteins. Three experiments were performed in each trial. Densitometry for each band is indicated in the bar graph.

siRNA treatments of PKC-ı resulted in significant decrease in PKC-ı level by 87 and 64\% in SK-MEL-2 and MeWo cell lines, respectively. PKC- $\zeta$ decreased by 11 and $0 \%$ which is not significant, while Bcl-2 significantly decreased by 68 and $84 \%$, vimentin decreased by 73 and $67 \%$, phospho vimentin (S39) significantly decreased by 92 and $81 \%$, E-cadherin 


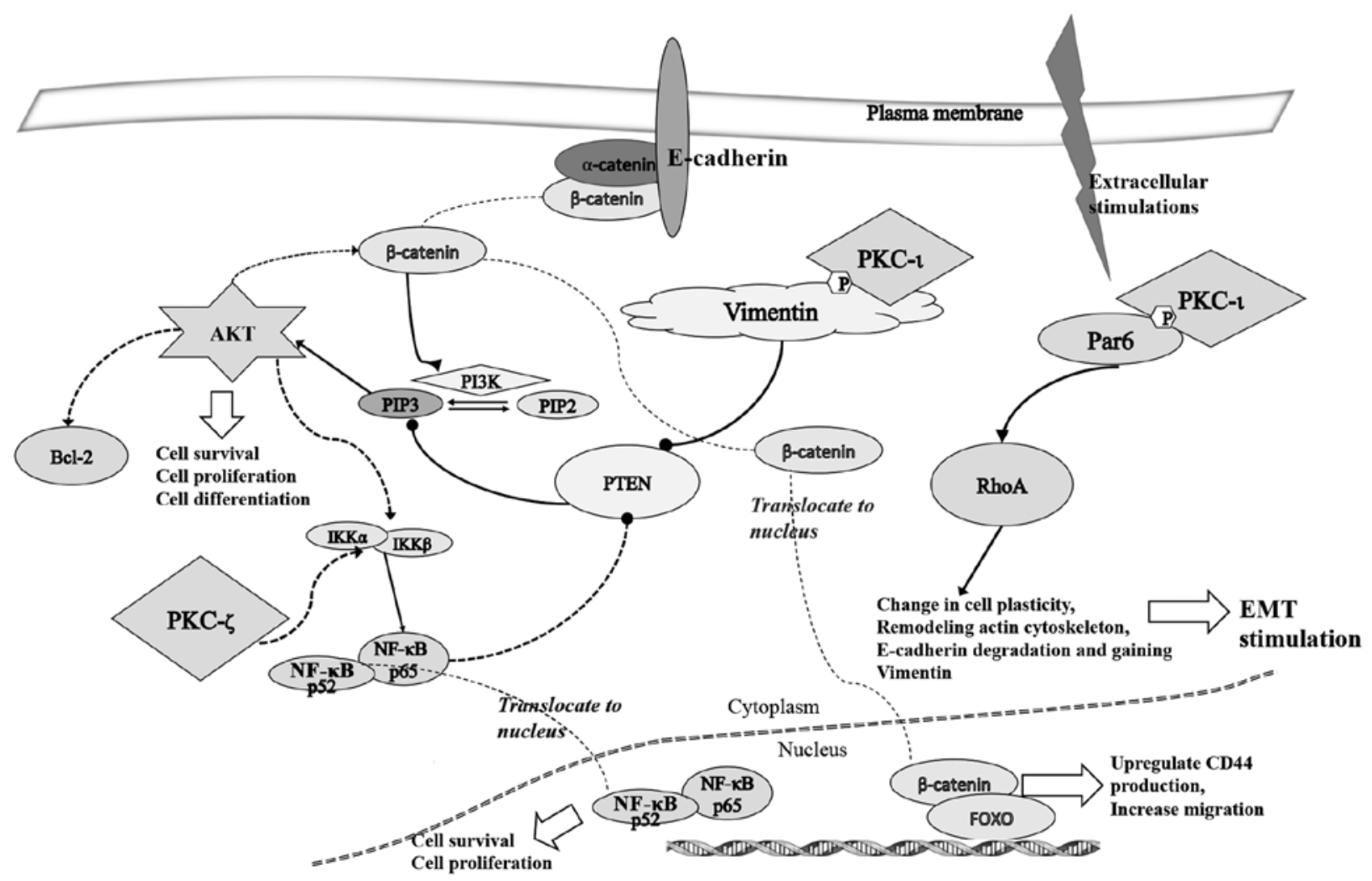

Figure 9. A schematic summary of the involvement of PKC-ı and PKC- $\zeta$ in melanoma progression. Upon extra cellular stimulation PKC-ı activate Par6, which leads to the degradation of RhoA and stimulate EMT by changing the cell integrity, loss of E-cadherin and gain of vimentin. During this process, cadherin junctions will be destabilized as a result of loss of E-cadherin and $\beta$-catenin will be translocated to nucleus to upregulate the production of some proteins such as CD44 which further stimulate migration and EMT. Importantly, PKC-ı tightly binds to vimentin to activate them by phosphorylation and this activated vimentin changes the cell polarity to maintain the mesenchymal phenotype. Activated vimentin can also stimulate the phosphorylation of PTEN leads to inactivation of inhibitory action of PTEN on PIP3 (48). This may result in activation of AKT through PIP3 and activated AKT pathway leading to cell survival, rapid proliferation and differentiation which are critical parts of melanoma progression. AKT could indirectly stimulate $\beta$-catenin translocation and activate NF- $\kappa$ B pathway in which PKC- $\zeta$ is known to play a stimulatory role on IKK- $\alpha / \beta$. It is reported that activated NF- $\mathrm{B}$ can inhibit PTEN (50).

increased by 59 and $46 \%$, RhoA increased by 33 and $26 \%$, Par6 decreased by 42 and 55\%, PTEN significantly increased by 94 and $88 \%$, phospho AKT (S473) decreased by 22 and $31 \%$ and NF- $\kappa$ B increased by 26 and $40 \%$ in PKC-ı siRNA treated SK-MEL-2 and MeWo cells, respectively.

siRNA treatments of $\mathrm{PKC}-\zeta$ resulted in significant decrease in PKC- $\zeta$ level by 83 and $76 \%$ in SK-MEL-2 and MeWo cell lines, respectively. PKC-ı decreased by 16 and $7 \%$ which is not significant, Bcl-2 significantly decreased by 71 and $62 \%$, vimentin decreased only by 9 and $13 \%$, which is not significant, phospho vimentin (S39) only decreased by 10 and $17 \%$, E-cadherin significantly increased by 20 and $14 \%$, Par6 decreased by 11 and 9\%, PTEN increased by 39 and 41\%, phospho AKT (S473) decreased by 29 and $28 \%$ and NF- $\kappa$ B increased by 37 and 35\% in PKC-ı siRNA treated SK-MEL-2 and MeWo cells, respectively. RhoA levels of PKC- $\zeta$ siRNA treated samples did not show a significant difference to its control. All significance values are indicated as $\mathrm{P} \leq 0.05$.

Association of $P K C-\iota$ and vimentin. We immunoprecipitated (IP) PKC-ı and PKC- $\zeta$ separately and WB experiments were conducted independently for E-cadherin, CD44, vimentin and $\mathrm{NF}-\kappa \mathrm{B}$ p65. PKC- $\zeta$ IP samples did not show any association with any mentioned proteins. Only vimentin immunoblot showed an association with PKC-ı IP samples (Fig. 8). This result suggests that $\mathrm{PKC}-\mathrm{\iota}$ associate with vimentin. To confirm this association, vimentin was immunoprecipitated, developed for said proteins and only PKC-ı was associated with vimentin.

\section{Discussion}

PKC- $\iota$ and PKC- $\zeta$ both have a wide range of effects and are overexpressed in many human cancers (4-7,31-33). Common upstream elements can activate both, but they each perform their own functions (34-37). The domains between PKC-ı and PKC- $\zeta$ are largely conserved; given nearly $70 \%$ of the similarity, it was important to identify inhibitors specific to aPKCs, and at the same time determine how much each was inhibited. A previous study showed the ACPD did not affect many upstream elements of the aPKC activation pathways (25-27). The computational screening and kinase activity assay data show that ACPD and DNDA are specific inhibitors of aPKCs. ACPD showed the same effect as an inhibitor for both PKC- $\zeta$ and $P K C-\iota$ in a relative sense. DNDA showed a better action on PKC-ı than PKC- $\zeta$ (Fig. 1G).

Determination of cell viability and cytotoxicity of malignant and normal cells after inhibitor treatments was necessary, considering our ultimate intent was to determine if the inhibitors had potential as therapeutic drugs. As observed in WST-1 experiments (Fig. 3A and D), neither 
inhibitor had any significant effect on the normal melanocyte cell viability. This in turn suggests that neither inhibitor proved toxic to the normal cells. Both ACPD and DNDA are cytostatic, rather than cytotoxic. Regardless, DNDA showed a mild toxicity towards both malignant melanoma cell lines, suggesting both inhibitors are effective against malignant cells without harming normal cells. This confirms the previous data, which suggested that malignant cells rely on aPKCs to remain viable $(8,7,38,39)$. As observed in the WB on normal melanocytes (Fig. 5A), normal melanocytes produced no detectable levels of PKC-ı, but they produced PKC- $\zeta$. Malignant melanoma cells (Fig. 5B) overexpressed both PKC-ı and PKC- $\zeta$. The total and phosphorylated levels of PKC-ı and PKC- $\zeta$ significantly reduced upon treatments with both ACPD and DNDA. Similarly, melanoma cell proliferation was markedly reduced (Fig. 2C-F) upon treatments while not observably affecting cell proliferation on normal melanocyte cells (Fig. 2A and B). This confirms that melanoma cellular functions are highly dependent on aPKCs, but normal melanocytes do not depend on aPKCs.

Previous studies have shown that overexpression of aPKCs have an anti-apoptotic effect in many cancers $(4-9,12)$. We could determine whether treatment with the inhibitors could induce apoptosis, we tested apoptotic markers through a WB (Fig. 5C). Increase in caspase-3, increase in PARP cleavage, and decrease in Bcl-2 all indicate apoptosis stimulation (40-43). Increase in caspase-3 levels is not always a direct indication of induction of apoptosis due to the tight binding of cleaved caspase-3 with X-linked inhibitor of apoptosis protein (XIAP). XIAP undergoes auto-ubiquitilation, but this process delays apoptosis until all XIAP is removed (44). Owing to this, we also tested direct PARP and cleaved PARP levels because PARP is a known downstream target for caspase-3. It cleaves more upon inducing apoptosis (45). We also tested Bcl-2 levels since it inhibits caspase activity by preventing xytochrome $c$ release from the mitochondria and/or by binding to the apoptosis-activating factor (APAF-1). ACPD and DNDA treatments each depicted an increase in apoptotic activity in both SK-MEL-2 and MeWo cell lines. The data confirm some previous results showing aPKCs have an anti-apoptotic effect. One major anti-apoptotic pathway is $\mathrm{NF}-\kappa \mathrm{B}$ activation, which entails aPKC releasing NF- $\kappa \mathrm{B}$ and $\mathrm{NF}-\kappa \mathrm{B}$ translocates to the nucleus to promote cell survival (46). Notably, the inhibitors not only reduced activity of aPKCs as evidenced by the kinase activity assay, but they also reduced the aPKC expression as shown in western blots. This suggests that aPKC activation plays a critical role in aPKC expression, but also that regulation mechanisms require further study.

In addition to apoptosis evasion, transformed melanocytes and melanoma cells also proceed through EMT. In this process, cells lose their epithelial characteristics to acquire the behavior of mesenchymal cells, thereby promoting individual cell migration and invasion from the primary site to distant organs. We tested the levels of vimentin, which is a mesenchymal marker produced in large quantities during EMT while cells inversely lose their E-cadherin $(12,13)$. We tested the expression of vimentin in normal melanocytes, but we found it undetectable. Even though the role of vimentin in EMT is not yet fully understood, vimentin is very important in gaining rear-to-front polarity for mesenchymal cells (47). We also tested $\beta$-catenin, which is a part of adherin junctions and involved in many functions, including coordination of cell-cell adhesion and gene transcription (48). $\beta$-catenin activation destabilizes the cell-cell junctions and $\beta$-catenin translocates to the nucleus, continuously driving transcription of targeted genes such as CD44. CD44 is a transmembrane glycoprotein upregulated by Wnt5A, and plays the role of an important mediator in tumor progression and cell invasion $(16,17,46)$. Both ACPD and DNDA showed promising effects on EMT markers, and E-cadherin levels increased upon treatments while CD44, $\beta$-catenin and vimentin levels all decreased. We also tested the levels of phosphorylated vimentin (S39), they decreased upon inhibitor treatments. The data suggest that the aPKC inhibition slows or possibly reverses EMT and supports the significant reduction observed in both migration and invasion of malignant melanoma cells upon treating ACPD and DNDA.

Immunoprecipitation and reverse immunoprecipitation of PKC-ı and vimentin showed a strong direct association between them (Fig. 8). To confirm inhibitor effects on melanoma, we treated the cells with siRNA for PKC-ı and PKC- $\zeta$. Results revealed that upon knocking down PKC-ı, total and phosphorylated vimentin levels significantly decreased by 73 and $93 \%$ for SK-MEL-2 cells, as well as 67 and $81 \%$ for MeWo cells. The effect of PKC- $\zeta$ knockdown on vimentin is negligible compared to the large effect we observed in PKC-ı knockdown. Our results suggest that both vimentin and PKC-ı work together changing the polarity in cancer cell migration. Vimentin activates upon the binding of PKC-ı and phosphorylates at Ser39. It has been previously shown that Par6 can be phosphorylated by aPKCs upon activation of TGF- $\beta$ receptors, and activated Par6 stimulates EMT in A549 adinocarcinoma cells $(11,49)$. TGF- $\beta$ activation stimulates degradation of RhoA and cells lose E-cadherin while increasing vimentin. Both inhibitor treatments increased the levels of E-cadherin and RhoA, indicating the inhibition of PKC-ı or PKC- $\zeta$ or both can lead to complete stop or reversal of melanoma EMT (Fig. 6). To confirm the results, we tested the levels of Par6 and RhoA and E-cadherin levels in siRNA treated cells (Fig. 7). Results revealed that PKC-ı knockdown increased both E-cadherin and RhoA effectively compared to the PKC- $\zeta$ knockdown. In PKC- $\zeta$ siRNA treatments, the RhoA effect is only negligible, though its effect on E-cadherin is less when one compares it to the PKC-ı knockdown. This suggests that only PKC-ı is responsible for stimulating EMT. TGF- $\beta$ stimulation also activates the $\mathrm{Wnt} / \beta$-catenin pathway; in that case, stabilized $\beta$-catenin translocates to the nucleus and inhibits metastasis suppressors in melanoma (16). Previous research supports our observations here that negative regulation of EMT is observed upon inhibition of aPKCs by ACPD and DNDA. It has been previously shown that activated Vimentin inhibits PTEN by increasing the phosphorylation of PTEN to enhance PI3K/AKT activity which leads to cell differentiation and survival of osteoblasts (50). This process can also inhibit apoptosis via the NF- $\kappa \mathrm{B}$ pathway (51). Increases in PTEN levels in both ACPD and DNDA treated samples and si RNA treated samples for PKC-ı and $\mathrm{PKC}-\zeta$ strongly support this statement. Notably, increased levels of PTEN in PKC- $\zeta$ treated siRNA samples suggested the involvement of PKC- $\zeta$. It has been published that PKC- $\zeta$ stimulates IKK $\alpha / \beta$, which 
ultimately stimulates translocation of $\mathrm{NF}-\kappa \mathrm{B}$ complex into the nucleus resulting in increased cell survival (52). Notably, we found increases in NF- $\kappa$ B p65 levels upon inhibitor treatments, but also upon both siRNA treatments. This may seem illogical, but previous studies have shown that expression of $\mathrm{NF}-\kappa \mathrm{B}$ p65 has a corresponding increase in $\mathrm{I} \kappa \mathrm{B}$, resulting in an auto-regulatory loop (52). It is possible that the upstream signaling for NF- $\kappa \mathrm{B}$ translocation is not being inhibited by negative feedback since translocation has been inhibited downstream, resulting in more $\mathrm{NF}-\kappa \mathrm{B}$ production. $\mathrm{NF}-\kappa \mathrm{B}$ is still inhibited from translocating to the nucleus. This causes cell mediated apoptosis and cell survival rate reductions. In summary (Fig. 9), our results suggest that PKC-ı is responsible for inducing EMT, while PKC- $\zeta$ is mainly involved in $\mathrm{NF}-\kappa \mathrm{B}$ signaling to promote cell growth and survival. In addition, PKC- $\iota$ is involved in stimulating AKT signaling by inhibiting PTEN via vimentin activation. Activated vimentin induces the phosphorylation of PTEN.

In conclusion, our results suggest that ACPD and DNDA are effective aPKC inhibitors in melanoma cells, and do not affect normal melanocytes. ACPD and DNDA can reduce the cell proliferation, migration and invasion, while inducing apoptosis. Results also show a direct relationship between vimentin, PKC-ı and EMT. aPKC inhibitors (ACPD and DNDA) can reduce EMT progression, or possibly reverse it by specifically inhibiting PKC-ı. Finally, collected evidence suggest ACPD and DNDA could be potential therapeutic drugs for malignant melanoma.

\section{Acknowledgements}

We acknowledge the generous financial contribution from the Frederick H. Leonhardt, the Daniel Tanner Foundation, the David R.Clare and Margaret C.Clare Foundation, the Elizabeth Ireland Graves Foundation, the Harvey R. Chaplin, Carl C. Anderson, Sr. and Marie Jo Anderson Charitable Foundation and the Charles and Ann Johnson Foundation. Moreover, we thank Ms. Rekha Patel for her excellent technical advice and Mr. Christopher Apostolatos and Ms. Michelle Wilde for their help in critically editing the manuscript.

\section{References}

1. Eggermont AM: Adjuvant ipilimumab in stage III melanoma: New landscape, new questions. Eur J Cancer 69: 39-42, 2016

2. Hao M, Song F, Du X, Wang G, Yang Y, Chen K and Yang J: Advances in targeted therapy for unresectable melanoma: New drugs and combinations. Cancer Lett 359: 1-8, 2015.

3. Melanoma of the Skin - Cancer Stat Facts: <http://seer.cancer. gov/statfacts/html/melan.html>, 03/30/2017.

4. Manning G, Whyte DB, Martinez R, Hunter T and Sudarsanam S The protein kinase complement of the human genome. Science 298: 1912-1934, 2002.

5. Koivunen J, Aaltonen V and Peltonen J: Protein kinase C (PKC) family in cancer progression. Cancer Lett 235: 1-10, 2006.

6. Regala RP, Weems C, Jamieson L, Khoor A, Edell ES, Lohse CM and Fields AP: Atypical protein kinase $\mathrm{C}$ iota is an oncogene in human non-small cell lung cancer. Cancer Res 65: 8905-8911, 2005.

7. Murray NR and Fields AP: Atypical protein kinase C ı protects human leukemia cells against drug-induced apoptosis. J Biol Chem 272: 27521-27524, 1997.

8. Acevedo-Duncan M, Patel R, Whelan S and Bicaku E: Human glioma PKC-iota and PKC-betaII phosphorylate cyclin-dependent kinase activating kinase during the cell cycle. Cell Prolif 35: 23-36, 2002.
9. Patel R, Win H, Desai S, Patel K, Matthews JA and AcevedoDuncan M: Involvement of PKC-iota in glioma proliferation. Cell Prolif 41: 122-135, 2008.

10. Regala RP, Thompson EA and Fields AP: Atypical protein kinase $\mathrm{C}$ iota expression and aurothiomalate sensitivity in human lung cancer cells. Cancer Res 68: 5888-5895, 2008.

11. Gunaratne A, Thai BL and Di Guglielmo GM: Atypical protein kinase $\mathrm{C}$ phosphorylates Par6 and facilitates transforming growth factor $\beta$-induced epithelial-to-mesenchymal transition. Mol Cell Biol 33: 874-886, 2013.

12. Kim KK, Kugler MC, Wolters PJ, Robillard L, Galvez MG, Brumwell AN, Sheppard D and Chapman HA: Alveolar epithelial cell mesenchymal transition develops in vivo during pulmonary fibrosis and is regulated by the extracellular matrix. Proc Natl Acad Sci USA 103: 13180-13185, 2006.

13. Wei J, Xu G, Wu M, Zhang Y, Li Q, Liu P, Zhu T, Song A, Zhao L, Han Z, et al: Overexpression of vimentin contributes to prostate cancer invasion and metastasis via src regulation. Anticancer Res 28 (1A): 327-334, 2008.

14. Selzer E, Okamoto I, Lucas T, Kodym R, Pehamberger H and Jansen B: Protein kinase C isoforms in normal and transformed cells of the melanocytic lineage. Melanoma Res 12: 201-209, 2002.

15. Ratnayake WS and Acevedo-Duncan M: Use of ACPD and ICA-1 as inhibitors of atypical protein kinase C-zeta $(\zeta)$ and iota (๖) in metastasized melanoma cells. Cancer Res 76 (14 Suppl): Abs 4569, 2016.

16. Dissanayake SK, Wade M, Johnson CE, O'Connell MP, Leotlela PD, French AD, Shah KV, Hewitt KJ, Rosenthal DT, Indig FE, et al: The Wnt5A/protein kinase $\mathrm{C}$ pathway mediates motility in melanoma cells via the inhibition of metastasis suppressors and initiation of an epithelial to mesenchymal transition. J Biol Chem 282: 17259-17271, 2007.

17. Weeraratna AT, Jiang Y, Hostetter G, Rosenblatt K, Duray P, Bittner $\mathrm{M}$ and Trent JM: Wnt5a signaling directly affects cell motility and invasion of metastatic melanoma. Cancer Cell 1: 279-288, 2002.

18. Qureshi R, Arora H and Rizvi MA: EMT in cervical cancer: Its role in tumour progression and response to therapy. Cancer Lett 356: 321-331, 2015

19. Pillai P, Desai S, Patel R, Sajan M, Farese R, Ostrov D and Acevedo-Duncan M: A novel PKC-ı inhibitor abrogates cell proliferation and induces apoptosis in neuroblastoma. Int $\mathrm{J}$ Biochem Cell Biol 43: 784-794, 2011.

20. Win HY and Acevedo-Duncan M: Role of protein kinase C-iota in transformed non-malignant RWPE-1 cells and androgenindependent prostate carcinoma DU-145 cells. Cell Prolif 42: $182-194,2009$

21. O'Connell MP, French AD, Leotlela PD and Weeraratna AT: Assaying Wnt5A-mediated invasion in melanoma cells. Methods Mol Biol 468: 243-253, 2008.

22. Win HY and Acevedo-Duncan M: Atypical protein kinase $C$ phosphorylates IKKalphabeta in transformed non-malignant and malignant prostate cell survival. Cancer Lett 270: 302-311, 2008.

23. Selbie LA, Schmitz-Peiffer C, Sheng Y and Biden TJ: Molecular cloning and characterization of PKC iota, an atypical isoform of protein kinase $\mathrm{C}$ derived from insulin-secreting cells. J Biol Chem 268: 24296-24302, 1993.

24. Xiao H and Liu M: Atypical protein kinase $\mathrm{C}$ in cell motility. Cell Mol Life Sci 70: 3057-3066, 2013.

25. Sajan MP, Acevedo-Duncan ME, Standaert ML, Ivey RA, Lee M and Farese RV: Akt-dependent phosphorylation of hepatic FoxO1 is compartmentalized on a WD40/ProF scaffold and is selectively inhibited by aPKC in early phases of diet-induced obesity. Diabetes 63: 2690-2701, 2014.

26. Sajan MP, Ivey RA III and Farese RV: Metformin action in human hepatocytes: Coactivation of atypical protein kinase $\mathrm{C}$ alters 5'-AMP-activated protein kinase effects on lipogenic and gluconeogenic enzyme expression. Diabetologia 56: 2507-2516, 2013.

27. Sajan MP, Ivey RA, Lee MC and Farese RV: Hepatic insulin resistance in ob/ob mice involves increases in ceramide, aPKC activity, and selective impairment of Akt-dependent FoxO1 phosphorylation. J Lipid Res 56: 70-80, 2015.

28. Wooten MW, Seibenhener ML, Zhou G, Vandenplas ML and Tan TH: Overexpression of atypical PKC in PC12 cells enhances NGF-responsiveness and survival through an NF-kappaB dependent pathway. Cell Death Differ 6: 753-764, 1999. 
29. Ukeda H, Maeda S, Ishii T and Sawamura M: Spectrophotometric assay for superoxide dismutase based on tetrazolium salt 3'-\{1-[phenylamino)-carbonyl]3,4-tetrazolium]bis(4-methoxy-6-nitro)benzenesulfonic acid hydrate reduction by xanthine-xanthine oxidase. Anal Biochem 251: 206-209, 1997.

30. Xu S, Wang H, Pan H, Shi Y, Li T, Ge S, Jia R, Zhang H and Fan X: ANRIL IncRNA triggers efficient therapeutic efficacy by reprogramming the aberrant INK4-hub in melanoma. Cancer Lett 381: 41-48, 2016.

31. Farese RV: Function and dysfunction of aPKC isoforms for glucose transport in insulin-sensitive and insulin-resistant states. Am J Physiol Endocrinol Metab 283: E1-E11, 2002.

32. Suzuki A, Yamanaka T, Hirose T, Manabe N, Mizuno K, Shimizu M, Akimoto K, Izumi Y, Ohnishi T and Ohno S: Atypical protein kinase $\mathrm{C}$ is involved in the evolutionarily conserved par protein complex and plays a critical role in establishing epitheliaspecific junctional structures. J Cell Biol 152: 1183-1196, 2001.

33. Du R, Lu KV, Petritsch C, Liu P, Ganss R, Passegué E, Song H, Vandenberg S, Johnson RS, Werb Z, et al: HIF1 $\alpha$ induces the recruitment of bone marrow-derived vascular modulatory cells to regulate tumor angiogenesis and invasion. Cancer Cell 13: 206-220, 2008.

34. Suzuki A, Akimoto $\mathrm{K}$ and Ohno S: Protein kinase C lambda/iota (PKClambda/iota): A PKC isotype essential for the development of multicellular organisms. J Biochem 133: 9-16, 2003.

35. Mamidipudi V, Lin C, Seibenhener ML and Wooten MW: Regulation of interleukin receptor-associated kinase (IRAK) phosphorylation and signaling by iota protein kinase C. J Biol Chem 279: 4161-4165, 2004.

36. Mah IK, Soloff R, Hedrick SM and Mariani FV: Atypical PKC-iota controls Stem cell expansion via regulation of the Notch pathway. Stem Cell Rep 5: 866-880, 2015.

37. Brady SC, Allan LA and Clarke PR: Regulation of caspase 9 through phosphorylation by protein kinase $\mathrm{C}$ zeta in response to hyperosmotic stress. Mol Cell Biol 25: 10543-10555, 2005.

38. Shultz JC, Vu N, Shultz MD, Mba M-UU, Shapiro BA and Chalfant CE: The Proto-oncogene $\mathrm{PKC} \mathrm{C}$ regulates the alternative splicing of Bcl-x pre-mRNA. Mol Cancer Res 10: 660-669, 2012

39. do Carmo A, Balça-Silva J, Matias D and Lopes MC: PKC signaling in glioblastoma. Cancer Biol Ther 14: 287-294, 2013.
40. Jänicke RU, Sprengart ML, Wati MR and Porter AG: Caspase-3 is required for DNA fragmentation and morphological changes associated with apoptosis. J Biol Chem 273: 9357-9360, 1998.

41. Kroemer G: The proto-oncogene Bcl-2 and its role in regulating apoptosis. Nat Med 3: 614-620, 1997.

42. Watson AJ, Askew JN and Benson RS: Poly(adenosine diphosphate ribose) polymerase inhibition prevents necrosis induced by H2O2 but not apoptosis. Gastroenterology 109: 472-482, 1995.

43. Soldani C and Scovassi AI: Poly(ADP-ribose) polymerase-1 cleavage during apoptosis: An update. Apoptosis 7: 321-328, 2002.

44. van Raam BJ, Drewniak A, Groenewold V, van den Berg TK and Kuijpers TW: Granulocyte colony-stimulating factor delays neutrophil apoptosis by inhibition of calpains upstream of caspase-3. Blood 112: 2046-2054, 2008

45. Cohen GM: Caspases: The executioners of apoptosis. Biochem J 326: 1-16, 1997

46. Kasof GM, Lu JJ, Liu D, Speer B, Mongan KN, Gomes BC and Lorenzi MV: Tumor necrosis factor-alpha induces the expression of DR6, a member of the TNF receptor family, through activation of NF-kappaB. Oncogene 20: 7965-7975, 2001.

47. Mendez MG, Kojima S and Goldman RD: Vimentin induces changes in cell shape, motility, and adhesion during the epithelial to mesenchymal transition. FASEB J 24: 1838-1851, 2010.

48. Chaw SY, Majeed AA, Dalley AJ, Chan A, Stein S and Farah CS: Epithelial to mesenchymal transition (EMT) biomarkers E-cadherin, beta-catenin, APC and Vimentin - in oral squamous cell carcinogenesis and transformation. Oral Oncol 48: 997-1006, 2012.

49. Gunaratne A and Di Guglielmo GM: Par6 is phosphorylated by aPKC to facilitate EMT. Cell Adhes Migr 7: 357-361, 2013

50. Xi G, Shen X, Rosen CJ and Clemmons DR: IRS-1 functions as a molecular scaffold to coordinate IGF-I/IGFBP-2 signaling during osteoblast differentiation. J Bone Miner Res 31: 1300-1314, 2016.

51. Brumatti G, Salmanidis M and Ekert PG: Crossing paths: Interactions between the cell death machinery and growth factor survival signals. Cell Mol Life Sci 67: 1619-1630, 2010.

52. Scott ML, Fujita T, Liou HC, Nolan GP and Baltimore D: The p65 subunit of NF-kappa B regulates I kappa B by two distinct mechanisms. Genes Dev 7 (7A): 1266-1276, 1993. 